\title{
The Digital Divide Is a Human Rights Issue: Advancing Social Inclusion Through Social Work Advocacy
}

\author{
Cynthia K. Sanders ${ }^{1}$ (i) $\cdot$ Edward Scanlon ${ }^{2}$
}

Accepted: 1 October 2020 / Published online: 19 March 2021

(c) Springer Nature Switzerland AG 2021

\begin{abstract}
The role of technology and importance of access to high-speed broadband has become glaringly obvious during the COVID19 pandemic. High-speed Internet is a tool people rely upon to conduct the daily business of their life and interact with each other, the economy, and government. However, millions of people in the USA still have no home access to high-speed Internet. Low-income, people of color, older, Native Americans, and rural residents in particular are on the wrong side of the digital divide. This structural reality perpetuates social, economic, and political disparities. Consistent with a social work human rights approach, the United Nations General Assembly declared access to the Internet a basic human right in 2016. This calls upon social workers to engage in advocacy efforts to advance policy and programs to alleviate the digital divide. In this article, we examine the digital divide in the USA and discuss why it is a social justice and human rights issue. We provide a policy context and recent examples of state or local policy initiatives to reduce the digital divide. Prominent among them is California's Internet for All Now Act. We also identify and share promising practices and advocacy tools being used in the field that provide guidance to community practitioners as they engage in work at state and local levels aimed at closing the digital divide.
\end{abstract}

Keywords Information technology $\cdot$ Digital divide $\cdot$ Human rights $\cdot$ Social work advocacy

\section{Introduction}

Imagine your day-to-day life without reliable, consistent, and rapid access to the Internet. What kind of impact would this have on your ability to communicate with others, stay in touch with family and friends, complete your schoolwork, look for a job, keep up on current events, or take care of your daily financial transactions? What kind of impact would this have had on your life during the pandemic of 2020? The role and importance of technology has become glaringly obvious in the context of the COVID-19 pandemic, where society has been forced to rely even more heavily on technology for basic daily living including accessing basic goods, maintaining connections with others, working from home, and having the ability to complete schoolwork.

Cynthia K. Sanders

cynthiasanders@boisestate.edu

1 School of Social Work, Boise State University, 1910 University Drive, Boise, ID, USA

2 School of Social Welfare, University of Kansas, Lawrence, KS, USA
However, completing these basic tasks is a major challenge for millions of people who either lack access to highspeed Internet or do not adopt it, creating disadvantages that affect their ability to participate in social, political, and economic lives in the USA. A high-speed Internet connection, also known as broadband, is an essential infrastructure for functioning in today's society. Those without access or adoption are in the digital divide. This structural reality effectively results in what has been called "digital redlining" and further perpetuates social and economic disparities in society (Neidig 2017; Gilliard 2016). This injustice calls on social workers to engage in policy and program initiatives to close the digital divide.

In this article, we examine the digital divide, who does and does not have access to an essential service that is part of the daily fabric of living in the digital era. We discuss why the digital divide is a human rights and social justice issue: one that social workers should be actively working to close through policy advocacy work. We examine what some states are doing to reduce the divide and are encouraged by steps in some communities to extend Internet service to many rural and marginalized groups. However, there is still 
much work to do in order to ensure everyone has access to reliable and high- speed Internet. In the final section of this article, we examine promising practices and advocacy tools utilized in the field that can assist community practitioners to engage in work at state and local levels aimed at closing the digital divide.

\section{The Digital Divide}

Librarian Jessamyn West (2011) offers a definition of the digital divide: "The digital divide is a simplistic phrase used to explain the gap between people who can easily use and access technology, and those who cannot. The term digital divide has been in common use to refer to the sense of technological haves and have-nots for over a decade" (Introduction, p. xxiv). In other words, some people are privileged in their access to and use of technology compared with others. This is due to a variety of factors, including computer ownership, high-speed Internet access and adoption, and digital literacy.

Mossberger et al. (2003) conceptualize the digital divide to consist of multidimensional aspects of technological inclusion: "an access divide, a skills divide, an economic opportunity divide, and a democratic divide" (p. 2). Highspeed Internet is a tool people increasingly rely upon to interact with the government, the economy, and each other. Increased home Internet use is associated with a significantly higher probability of contacting government officials in various ways. In a 2010 study by political scientists Dari Sylvester and Adam McGlynn, Internet usage was found to increase political participation by providing information that can increase one's political efficacy, including acts such as letter writing, phone calls, and sending e-mails to government. The results demonstrate that those who do not use the Internet at home, whether due to inadequate knowledge or lack of access, are less likely to be civically active. Thus, the digital divide can have significant negative consequences for political participation.

While an extensive discussion of the history of Internet development is beyond the scope of this paper, it is important to note that there is good reason to argue that broadband should be a public utility. Indeed, billions of dollars in public funding are responsible for the mobilization and development of the Internet (Tarnoff 2016). The roots of the Internet go back to the 1960s when the public entity Advanced Research Projects Agency (ARPA) began to invest heavily in computing, building mainframes at universities and other research sites. The precursor to the Internet was the network built by ARPA called ARPANET. Through public funding, scientific collaboration, experimentation, and innovation ARPANET flourished. In the mid-1970s, the development of Internet protocols emerged as a common language between very different networks and made it possible for ARPANET to evolve into the Internet. The National Science Foundation undertook initiatives to bring the Internet to universities across the country. These efforts culminated in NSFNET, a national network that became the new backbone of the Internet. As popularity of the Internet grew, so did congestion and demand beyond capability (Tarnoff 2016).

Beginning in the 1990s, the US government began a process of privatizing a network built at tremendous public expense. The free market and deregulation climate of Clinton Democrats and Newt Gingrich's Republicans framed private ownership of the Internet as beneficial and inevitable. NSFNET director Stephen Wolf believed privatizing the Internet could avoid political and technical challenges and that liberation from government control would allow the Internet to become a mass medium. Today, the Internet backbone and broadband are held by relatively few large corporations that dominate the market (Tarnoff 2016). Developing the Internet was historically a radical and financially risky idea. It took decades of public funding and planning to bring it into existence. The development of the Internet can be thought of as akin to other public utilities such as water and electricity. It can be compared with the US road grid or the US Postal Service that reaches everyone. Left to its own devices, the private market will not provide access to everyone at affordable prices but rather systematically provide expensive services for the richest people in order to make profits at the expense of the social good (Klein 2014).

Thus, there is an argument to be made that the Internet should be a publically owned and controlled utility. Indeed some municipalities have forcefully responded with publicly owned and affordable municipal broadband. For example, Chattanooga, TN, using a fiber-optic network built in part with federal stimulus funds, offers some of the fastest Internet speeds in the world at affordable prices (O'Toole 2014). The "Chattanooga model" has inspired movements for municipal broadband in several other cities (Tarnoff 2016).

The digital divide not only includes the obvious issues of access to computers and connectivity but also includes issues of inequity affecting those who either lack the skills and opportunities to access information technology or who are in a less equal position in terms of use (Makinen 2006). As research into the digital divide progresses, the need for digital literacy is highlighted. In some cases, those with low digital literacy may begin to gain access and enter the "haves" in technology but may demonstrate reluctance to the use of technology simply because they do not know how (Real et al. 2014). Educating and training both individuals and library and information (LIS) professionals are crucial components in the digital divide in order to provide information congruent with ever-changing technology and points of access. 
A goal for using information technology (IT) becomes the promotion of social inclusion among marginalized groups. That is, closing the digital divide requires access and enhancement of the abilities of individuals and groups to use IT to engage in meaningful social practices. Access to broadband Internet has been credited with effects on individual empowerment, community development, and economic growth (Jayakar et al. 2016). Historically, people have relied upon the US Postal Service (USPS) for access to information, a means of communication, and their ability to deliver essential items like medication, legal notices, and ballots. USPS's overall financial condition has been deteriorating for several years (GAO 2017), and its sustainability is under attack by the Trump administration (Waldman 2020). Thus, perhaps now more than ever, it is important for social workers to advocate for an inclusive high-speed Internet that replicates in the digital age what the postal service originally sets out to do in providing the nation with a reliable, affordable, and universal service (USPS 2011).

\section{Broadband Access}

While Internet access has grown among all socioeconomic categories, significant differences by age, income, ethnicity/race, and educational level persist (Warf 2012). Geographical location is also a leading factor, with rural communities much less likely to have access to high-speed Internet (West and Karsten 2016). A large disparity also exists for those living with a disability. Approximately $81 \%$ of adults use the Internet; however, only $51 \%$ of adults living with a disability access the Internet (Fox 2011).

According to the most recent Federal Communications Commission (FCC) deployment report (FCC 2019), an estimated 21 million Americans still have no home access to high-speed Internet service, defined by the FCC as a download speed of $25 \mathrm{Mbps}$ and upload speed of $3 \mathrm{Mbps}$. The majority live in rural areas (McGill 2018). These data most likely underestimate the number of people who do not have access to broadband, as the FCC's data are widely considered to overestimate broadband connectivity (Pew Research 2020; Lecher 2019; GAO 2018). Other sources estimate this number as high as 162 million people across the USA who are not using the Internet at broadband speed (Microsoft 2019). Based on the 2018 Broadband deployment report, as of the year end 2016, 92.3\% of all Americans had access to fixed terrestrial broadband at speeds of $25 \mathrm{Mbps} / 3 \mathrm{Mbps}$, up from $89.4 \%$ in 2014 and $81.2 \%$ in 2012 . While the overall trend in access is improving, patterns of exclusion persist (FCC 2018).

\section{Broadband Adoption}

Availability of broadband does not equal adoption. Adoption of broadband is equally important to ensure the benefits (including economic benefits) that go along with Internet use to everyone. While broadband may be available, broadband adoption refers to the extent to which US households subscribe to and use broadband. Populations who continue to lag in broadband adoption, even when available, include people with low incomes, older adults, minorities, the less educated, non-family households, the unemployed, and limited English-speaking households (Kruger and Gilroy 2019; Ryan 2018). According to Census data from the 2016 American Community Survey, $81.4 \%$ of American households have a broadband Internet subscription. Census data from July 2015 show that $68 \%$ of Americans use the Internet at home. However, in 2015, 73.3 million (almost a quarter of the nation's population) lived in neighborhoods where in-home broadband subscription rates fell below $40 \%$. These residents tend to be older, have lower incomes and lower education levels, and subscription rates remain lowest in rural America. These numbers also include 17.7 million children under the age of 18 (Tomer et al. 2017). For children, living without in-home broadband means losing the benefits from digital curricula or developing digital skills for the future workplace among other things. And the challenges are great for schools and school districts serving non-subscribing households. Data from the Pew Research Center demonstrate that certain groups, unable to afford the cost of monthly subscriptions, continue to lag in the adoption of broadband including people with low incomes, older adults, those with less education, rural households, and those on tribal lands and US territories (Kruger and Gilroy 2019).

Digital readiness/literacy also plays an important role in adoption rates. Digital readiness (digital skills such as ability to use hardware and software to communicate, manage information, navigate the Internet, identify threats and safety issues) and access to equipment are other consistent adoption barriers. A lack of digital readiness is most prevalent among older, non-Asian minority, less-educated, and lower-income individuals (Horrigan 2016).

\section{Low-Income Households}

The main reason some families do not have home computers or subscribe to the Internet is because they cannot afford it (Rideout and Katz 2016). People who fall lower on the economic ladder are more likely to be people without access or unable to adopt the Internet resulting 
in falling further behind and widening the digital divide between rich and poor. According to 2015 National Telecommunications and Information Administration data, the digital divide varies by family income. Americans with family incomes between $\$ 75,000$ and $\$ 99,999$ per year adopted the Internet at an $83 \%$ rate, compared with $80 \%$ with incomes between $\$ 50,000$ and $\$ 74,999$ and $70 \%$ for those in the $\$ 25,000$ to $\$ 49,999$ range. Pronounced disparities exist for those living in rural areas compared with urban ones (Carlson and Goss 2016). Nearly half (48\%) of all households have "high connectivity" meaning households with a laptop or desktop, a smartphone, a tablet, and a broadband Internet connectivity. However, among household with an income of $\$ 150,000$ or more, $80 \%$ of households had high connectivity while this was true for only $21 \%$ of households with an income under $\$ 25,000$ (U.S Census 2017). Additionally, states with higher incomes reported high rates of use and access while low-income states including Arkansas and Mississippi had the lowest rates of broadband use at $71 \%$. (Ryan 2018).

The majority (91\% overall) of people living in poverty have at least some form of Internet access (Rideout and Katz 2016). However, lower-income adults rely more heavily on smartphone-only access. In 2019, $26 \%$ of adults making $\$ 30,000$ or less relied on smartphones for Internet access compared with $20 \%$ of those making between $\$ 30,001$ and $\$ 49,999,10 \%$ of those making $\$ 50,000-\$ 74,999$, and only $6 \%$ of those making $\$ 75,000$ and above (Pew Research 2019). Mobile-only families are less likely to do certain types of online activities including staying in touch with family and friends, getting news, looking for general information, bank or pay bills online, shop online, and apply for jobs or services. With just a mobile device, it is very difficult to do things like help children with homework (Rideout and Katz 2016).

This pattern of income variation in broadband connectivity not only affects households but also occurs at the neighborhood level. Tomer et al. (2017) found that low-income neighborhoods have the lowest subscription rates and that the opposite is true for high-income neighborhoods, where only $3 \%$ of residents lived in low-subscription neighborhoods. Not surprisingly, these patterns support the notion that those left behind in the digitally connected economy are those who are already struggling economically.

\section{Race and Ethnicity}

With the degree to which Internet access and adoption is paramount to social mobility, racial disparities stand to reproduce and perhaps exacerbate broader, racialized patterns. Blacks and Latinos are equally likely to report having Internet access, but both groups are less likely to report having Internet access than Whites. While access to the Internet has increased for all racial groups, access disparities for Blacks, Latinos, and Native Americans persist compared with Whites (Campos-Castillo 2015; FCC 2020).

Based on census data in 2015, the percentage of households with no broadband or computer disproportionately impact Blacks and Hispanics at rates of 36.4 and 30.3\%, respectively, compared with only $21.2 \%$ of White households who have neither broadband or a computer (US Census 2017). Families headed by Hispanic immigrants are the least connected among low and moderate income families (Rideout and Katz 2016). Households with an Asian head of household were the most likely to own or use a laptop or desktop, to own or use a smartphone, to own or use a tablet, and to have a broadband Internet subscription. On the other hand, Black heads of household were the least likely to own or use a desktop or laptop or have a broadband subscription (Ryan 2018).

Approximately one in five adults, especially young adults, in the USA are smartphone-only Internet users. These smartphone-only users are more likely to be Black or Hispanic (Pew Research 2019). This is congruent with smartphone-only use among low-income households since we know that Black and Hispanic persons are disproportionately poor (Macartney et al. 2013). This could suggest that some people are increasingly comfortable using their phones rather than a computer. However, it is also because cell-only Internet users are younger heads of household of color with low incomes and less education who may resort to choosing between a phone or a computer and are thus forced to forgo the advantages and speed of conducting Internet business on an in home computer (Pew Research 2019; Duggan and Smith 2013).

\section{Education}

People with lower levels of education are more likely to find themselves within the digital divide. In 2015, for example, the digital divide was greatest between rural and urban users without a high school diploma. Only $52 \%$ of those who lack a high school diploma and live in a rural area reported using the Internet, compared with 59\% of those who live in urban households (Carlson and Goss 2016).

Variations in public school funding are reproduced in terms of quality of Internet access within their classrooms, and the digital divide in public schools is also racialized with White students more likely than students of color to use the Internet in the classroom or school library (Warf 2012). And, while many students can utilize broadband capabilities within school facilities, many students will not be able to tap their device's full potential at home. Additionally, a lack of access and in-home equipment can have 
a negative impact on school enrollment for youth (Tomer et al. 2017; Fairlie 2005).

For students who cannot get online at home, either because they lack access or because their families are socioeconomically disadvantaged and they cannot afford monthly charges to stay connected, learning starts and stops at the classroom door. According to Karl Vick (2017), policymakers trade stories of children completing assignments by using Wi-Fi outside of closed libraries or camping out in fast food restaurants. Children may try to complete homework on their phones but run out of data before they can complete their work. In some areas, it can be even more difficult if communities are relying on satellite dish technology, which is slower and more expensive.

Children who lack access to digital resources miss out on other enhancements as well, with disadvantaged students lacking or holding inferior technological resources at home compared with more privileged students (Ritzhaupt et al. 2013). For example, technology can enhance learning in various positive ways such as through e-books and animation. In a similar vein, the National Council of Teachers of Mathematics (2015) indicates that the effective use of technology can increase interest and proficiency in mathematics. Unfortunately, technology is not distributed evenly in schools. Teachers in low-income districts tend to incorporate digital resources in a less than optimal manner compared with those in wealthier areas (Rienhart et al. 2011).

This information paints a picture of some of the challenges faced in education prior to the COVID-19 pandemic. COVID-19 forced most schools to rapidly shifted entire curricula to online platforms. A recent New York Times editorial (2020) highlighted digital inequality among school age children when the country responded to the coronavirus by shutting down schools. Before the pandemic, an estimated 12 million children were having difficulty completing homework assignments because they lacked home Internet. A disproportionate share of those students are African-American, Hispanic, live in rural areas, or come from low-income families (Walravens 2020). Internet-savvy school systems appeared to move forward relatively smoothly. However, some districts that lack infrastructure and serve largely poor populations are scrambling to deliver remote learning (Bentley 2020). A number of states have been forced to reckon with how the digital divide is impacting their youngest residents. For example, Idaho launched a media campaign called "Close the Divide" recognizing that 200,000 students in Idaho lack a computer and 30,000 do not have access to Wi-Fi. This is about $11 \%$ of the 1.8 million residents of Idaho. The campaign is seeking donated laptop computers and financial contributions to buy computers and increase Internet access (Close the Divide 2020). While initiatives like this one are valued, it is unfortunate that it required a pandemic to highlight the divide and advance efforts to close it.

\section{Urban/Metro vs. Rural and Tribal Communities}

An issue commonly raised in the literature is the digital divide between urban and rural communities, especially in terms of their differential access to broadband (West and Karsten 2016). Since the dawn of the Internet, rural areas have had less Internet access than urban areas. High-speed wired connections are less common, and wireless phone service and signals are weaker than in cities (or absent all together). Rural residents have fewer choices of Internet service providers (or none at all), pay higher prices for lower quality service, and generally earn less money than urban dwellers. Disparities could have adverse economic and social consequences for those left behind. A number of studies have demonstrated positive relationships between availability of broadband and greater economic growth in employment, number of business overall, and greater growth in median household incomes (Kruger and Gilroy 2019).

Broadband is currently largely deployed by the private sector and thus profit-driven. Because of this, there is less incentive for companies to invest in broadband in rural areas than in urban areas where there is more demand and where customers are more likely to have higher incomes and less cost to wire the market area. Broadband providers are less likely to enter rural markets due to the actual or perceived lower profitability of markets with lower population densities or rugged terrain which may be difficult to reach or build technological infrastructure (GAO 2006). There is less money to be made with lower population densities and running wires to rural areas costs more.

According to the FCC as of the end of 2017, over 26\% of Americans in rural areas and $32 \%$ of Americans on tribal lands lack coverage from fixed terrestrial $25 \mathrm{Mbps} / 3 \mathrm{Mbps}$ broadband, compared with only $1.5 \%$ of Americans in urban areas (FCC 2019). Approximately 14 million rural Americans and 1.2 million Americans living on tribal lands in 2017 lacked even low-speed mobile LTE broadband of speeds of $10 \mathrm{Mbps} / 3$ Mbps (FCC 2018). According to Traci Morris, Director of the American Indian Policy Institute at Arizona State University, accurate measures of Internet access are lacking and thus likely overestimate connectivity because nationwide reports that measure digital access and literacy typically exclude Native American Populations (ASU 2019). While mobile phones are a tool to help residents on Native American land get online, many communities do not have reliable cell coverage nearby (Wang 2018). Tribal communities stand out as being among the most unserved and underserved populations with respect to broadband deployment. 
Writing in Politico, author Martha Harding McGill (2018) notes that nowhere is the digital divide more extreme than on tribal lands. According to the FCC (2020) "by virtually any measure, communities on tribal lands have historically had less access to telecommunications services than any other segment of the population" (p. 5).

While libraries play a vital role in rural and tribal locations to Internet access, they too lag behind more urban areas. According to a study by the Association of Tribal Archives, Libraries, and Museums, 89\% of tribal libraries that responded to a 2013 survey offer Internet access to patrons compared with $100 \%$ of public libraries (Jorgensen et al. 2014). At least $40 \%$ of tribal libraries lacked broadband Internet, and $14 \%$ of tribal libraries did not offer public computer workstations. While $86 \%$ of rural public libraries offer some form of free public $\mathrm{Wi}-\mathrm{Fi}$, only $68 \%$ of tribal libraries do; however, only $17 \%$ of tribal libraries in the study were able to provide Wi-Fi access when the library is closed. Eleven percent do not offer Internet access at all, and only $34 \%$ of tribal libraries had a website. Compared with public libraries nationwide, fewer tribal libraries can offer electronic resources for homework, licensed electronic databases, e-books, and online instructional courses and tutorials. While $87 \%$ of rural public libraries and $90 \%$ of all public libraries offer some type of training in technology, only $42 \%$ of tribal libraries offer similar training.

Rural students are severely restricted from educational opportunities compared with their urban counterparts including personalized online curricula, Internet-based research, and online testing. Further, rural communities may be unable to access critical government services that are increasingly provided through online portals such as Social Security, tax forms, and college student financial aid forms (West and Karsten 2016). Americans who are otherwise less likely to use the Internet, such as those with lower levels of income or education, confront an even larger disadvantage when living in a rural area. According to data collected by the National Telecommunications and Information Administration (NTIA), all persons, regardless of race or ethnicity, were less likely to use the Internet when living in rural areas; however, certain groups face a particularly large digital divide (Carlson and Goss 2016).

In metro areas, the biggest shortfalls are in the South, especially Oklahoma, Mississippi, and Georgia (Tomer et al. 2017). Within large metro areas, neighborhoods without broadband service are largely suburban. However, due to density, the largest absolute number of residents in lowsubscription neighborhoods lives in areas that are more populous overall and includes four of the largest areas in the nation; Los Angeles, Houston, Dallas, and Chicago. In other words, while each metro area is below average in terms of the share of people living in low subscription neighborhoods, collectively, this group is composed of 5.7 million people. So, while rural communities are much more likely to lack access to broadband, many metro area neighborhoods also fail to connect significant number of residents to existing broadband service. Residents living in low subscription rate neighborhoods can be found in urban, suburban, and small metropolitan communities alike, but by far, access and subscription rates remain lowest in rural America (Tomer et al. 2017).

\section{Digital Access Is a Human Rights and Social Justice Issue}

According to the United Nations, human rights are inherent to all human beings regardless of their status. Human rights include freedom from slavery and torture, the right to life and liberty, the right to work and education, freedom of opinion and expression, and equality and non-discrimination. Human rights include covenants on civil, political, economic, social, and cultural rights. Under international human rights law, it is incumbent upon nations and states to engage in or refrain from acts in order to promote and protect human rights (UN, n.d.). In recent years, social work's historic commitment to social justice has been advanced through the promotion of a human rights approach. The human rights approach turns social work's response to individual human need to a more expansive view that the resources necessary for survival and the development of human potential should be available to all as a right based upon our common humanity. In this view, resources must be distributed broadly within a framework that sees such a dispersal of social goods and resources as necessary for equitable human development and the social inclusion necessary for the development of democratic institutions (Murdach 2011; Wronka 2016). Given the central role that the Internet plays in today's digital age in gaining access to resources, jobs, health care, and education among others, universal access to broadband clearly falls within the realm of human rights.

Consistent with this approach, we see that around the world, access to high-speed Internet is increasingly seen not just as a convenience, but as a necessity and more recently as a human right. The United Nations has created a comprehensive body of human rights law to which nations can subscribe and people can aspire. The foundations of this body of law are the Charter of the United Nations and the Universal Declaration of Human Rights. Major social work organizations affirm this Declaration including the International Federation of Social Workers (IFSW 2012). One of the Council on Social Work Education's competencies includes advancing human rights and social, economic, and environmental justice (CSWE 2015).

In 2016, an addition was made to Article 19 of the Universal Declaration of Human Rights (United Nations General 
Assembly 2016). The United Nations General Assembly declared access to the Internet a basic human right, integral to allowing individuals to "exercise their right to freedom of opinion and expression" and emphasizing "access to internet facilitates vast opportunities for affordable and inclusive education." Additionally, viewed globally, the UN also stressed the importance of "the empowerment of all women and girls" by enhancing their access to information and communication technology (p. 2-3). According to the International Telecommunication Union (2016), while the USA has a small gender gap (2\%) in access to the Internet, there is a large gap in the world's least developed countries (LDCs) at $31 \%$.

With the advancement of technology comes the evolution of need. Today, computers and access to and adoption of the Internet impact multiple areas of our lives and have become vital to a wide range of functions from basic tasks like paying bills and shopping, to entertainment and socializing, to staying connected to family and friends. Internet access has become an avenue for finding employment, accessing health care, and pursuing formal education through online degree programs, to searching for information for more informal learning (e.g., how do I unclog my kitchen sink?). Those who lack Internet access are deprived of knowledge that could assist them in obtaining jobs, lower consumer prices, online entertainment, and many other necessities (health care, banking, communication with children's school and teachers, etc.). Without government support of human rights little progress can be made to incorporate them into policy and practice. The USA has a mixed record on its commitment and actions on human rights (Human Rights Watch 2019). Sadly, while the Internet began as a public investment, which theoretically should support access for all and thus reinforce a human right's framework to support each human being in realizing their inherent dignity and autonomy, privatization has resulted in the digital divide. Nonetheless, this should not prevent social workers from advancing inclusive policies and practices premised on the integration of human rights to close the divide.

Digital exclusion amounts to social exclusion where lack of information and digital technology negatively impacts personal, political, and economic capabilities. Individuals and communities are socially excluded when for reasons beyond their control, they are unable to participate in the normal activities of society (Burchardt et al. 1999). Everyone should have equal access to the Internet and have the opportunity to interface effectively through universal broadband access and by means of digital literacy training where needed in order to help people use the Internet well. Social work ethics call for social workers to ensure clients' access to services, as well as to provide culturally competent, inclusive, and affirming services (NASW 2017).
Social workers are committed to promoting social justice and access to resources that allow individuals and communities to more fully meet basic needs, promote well-being, and reach their capabilities in a complicated society. It has become increasingly clear, and during the recent pandemic glaringly obvious, that access to information and communication technology (ICT) and a broadband infrastructure to support it is an essential human right in order to function in today's society. When millions of people, disproportionately low-income, people of color, Native American and rural residents, find themselves on the wrong side of the digital divide, it calls upon social workers to engage in advocacy efforts to advance policy and programs to alleviate the divide.

Social work literature on integrating technology into practice and social work curriculum is on the rise (Belluomini 2017; Perron et al. 2010; Cosner Berzin et al. 2015; Allen et al. 2010; Stuhlmiller and Tolchard 2009; VanDeMark et al. 2010; Youn 2007). However, there is relatively little social work literature on the topic of policy advocacy to close the digital divide (Kuilema 2012; Queiro-Tajalli et al. 2003). At the same time, the US National Association of Social Workers (NASW) has compared broadband access with other vital services and utilities including water and electricity (Pace 2010). A recent publication by NASW (2017), in a joint statement with the Association of Social Work Boards, Council on Social Work Education, and the Clinical Social Work Association on standards for technology in social work practice, acknowledges the importance of technology in enhancing social workers' ability to engage in social action, develop social policy, and promote social justice (p. 21). They also note the importance of advocating for access to electronic services as part of social workers' commitment to social justice (p. 26).

\section{Policy Context and Policy Efforts}

The Telecommunications Act of 1996 addressed the issue of whether the Federal Government should intervene to prevent the digital divide in broadband services. Section 706 requires the Federal Communications Commission (FCC) to determine whether "advanced telecommunications capability is being deployed to all Americans in a reasonable fashion" (U.S. Senate Bill 652- Telecommunications Act of 1996). Historically, court rulings have upheld net neutrality prohibiting broadband companies from blocking or slowing the delivery of Internet content to consumers and maintaining the notion that the Internet is as critical as phone service or power (Kang 2016). Net neutrality preserves the FCC's authority to regulate Internet service providers (ISPs) and the Internet infrastructure to ensure that everyone has equal access. The concept of net neutrality is that all data traffic 
on a network should be treated indiscriminately and Internet service providers would be restricted from blocking, slowing down, or speeding up delivery of online content at their discretion. The debate surrounding net neutrality is essentially about how Internet service providers should be regulated, or not, and what role government should play in overseeing their network practices (Morton 2019).

The FCC's National Broadband Plan to promote digital inclusion includes a combination of sufficient broadband service, affordable broadband service, and the availability of opportunities to develop the digital literacy needed to use broadband (Jaeger et al. 2012). However, the FCC and federal communications' involvement in ensuring Internet access for all continues to be a source of heated debate. President Obama for example offered his view on broadband connectivity in a video from November 10, 2014, which in essence would have resulted in policies that would have radically changed the way that Internet is viewed by the government, resulting in broadband being seen as a public utility (Zeke 2014). In 2015, the FCC released an Open Internet Order with extensive rules to ensure Internet users equal and open access (Ruiz 2015). However, more recent actions under the Trump administration and FCC chairman Ajit Pai include the FCC's Restoring Internet Freedom Order and transparency rule amendments. Taking effect June 11, 2018, this order overturned earlier requirements on net neutrality for Internet service providers and placed primary jurisdiction over Internet service providers' network management practices under the Federal Trade Commission. Further, it preempted states from enacting similar network restrictions found in the 2015 Open Internet Order (Morton 2019). Nonetheless, 29 states and Puerto Rico responded by introducing net neutrality legislation in 2019 (Morton 2019).

FCC chairman, Ajit Pai, was appointed by President Trump and made repeal of rules and deregulation of the Internet a top priority, suggesting that it would help encourage innovation and help propel the economy (McCabe 2019). Led by New York Attorney General Eric Schneiderman, 22 states, the District of Columbia, and Internet company Mozilla, a lawsuit was filed against the FCC and efforts to dismantle net neutrality in the US Court of Appeals for the District of Columbia (Kang 2019). In October 2019, the federal appeals court upheld the repeal of regulations, but ruled the FCC overstepped by seeking to broadly stop states and local governments from implementing their own net neutrality rules (McCabe 2019). This ruling sets a precedence for the FCC to no longer regulate Internet service providers and diminishes the idea that high-speed Internet delivery should be treated as if it were a public utility. Sadly, this is in stark contrast to the declaration that access to the Internet is a basic human right. Net neutrality is likely to continue to be an ongoing debate at federal, state, and local levels and in the courts.
Recognizing the importance of broadband and the gap that results between resources and opportunities available to those who live in communities with robust networks and those who do not, a number of states are making efforts to close the gap in the absence of adequate federal action. For example, in New York City, OneNYC launched in 2015 by Mayor Bill de Blasio, aimed to provide every resident and business in New York with access to adequate and affordable broadband by 2025 (Nyc.gov 2015). It also focused on providing people with IT and technology skills, as well as providing improved Internet access throughout the city and offered dedicated support to senior citizens and young people and their families. Another example is LinkNYC, which is focusing on repurposing New York's payphone infrastructure with free Wi-Fi-with at least 7500 payphone kiosks planned for installation by 2025 , providing high-speed broadband to residents. The Smart Communities program in Chicago offered digital literacy and other training in low-income neighborhoods. Results demonstrated that more residents accessed job and health care services when a neighborhood-wide intervention to promote broadband use was implemented and confirm that neighborhoods struggling with broadband subscription are important focus areas for inclusive economic development planning (Tomer et al. 2017).

A recent expansive effort is the state of California's Internet for All Now Act, which attempts to reduce the digital divide for the 5 million California residents who lack access to reliable high-speed Internet services. Recognizing that broadband is a key component in building healthy economies and educational systems and acknowledging that many rural and low-income communities go unserved or underserved in the digital age, California passed the Internet for All Now Act in 2017. Assembly Bill 1665 (the Internet for All Now Act) was introduced in the California State Legislature on February 17, 2017, by Assembly member Eduardo Garcia with multiple joint and coauthor assembly members. The bill allocates $\$ 330$ million and extends the California Advances Services Fund (CASF) toward broadband deployment in low-income and rural areas by amending sections of the public utility code (California AB No 1665 2017).

The Internet for All Now Act received overwhelming bipartisan support in both houses and moved on to be signed by Governor Jerry Brown on October 15, 2017. The new law took effect on January 1, 2018. The bill package includes funding to expand access to broadband and support for digital literacy programs in communities previously deprived of reliable Internet connection (Wood 2017). California previously had a goal of expanding broadband infrastructure to $98 \%$ of California households. The goal of the Internet for All Now Act is to expand this goal to $98 \%$ of every geographical region of the state ensuring that rural communities are not left out of expansion efforts. In fact, 
the law stipulates that infrastructure projects in unserved or underserved regions are to receive funding first. In addition to broadband infrastructure, the bill includes an account directed toward unserved public housing communities. Additionally, money is available through the broadband adoption account to advance digital literacy training, public education, and outreach programs to increase broadband adoption by consumers, in particular those who are low-income, older adults, and communities facing socioeconomic barriers to broadband adoption.

California has also been a leader in seeking to maintain net neutrality, approving a law in 2018 that effectively restored the Obama-era federal rules at the state level (McCabe 2019). This law was passed in response to the Restoring Internet Freedom order under the Trump administration and FCC chairman, Ajit Pai, discussed earlier. Unfortunately, the California law is currently being held due to a lawsuit filed by the US Justice Department asking a federal judge to block implementation (Castro 2020).

The approach of advancing broadband and reducing the digital divide in California is to encourage public-private partnerships and leverage private investment, maximize available federal funding (such as through the federal Connect America Fund), and administer the CASF to promote the most cost-effective and equitable progress in access to and adoption of the Internet across California. Despite certain limitations, the Internet for All Now Act makes strides toward closing the digital divide in California and advancing inclusion of marginalized groups, particularly low-income and rural residents, thus advancing social and economic justice for Californians in the Digital Age.

\section{Overcoming the Digital Divide}

Bringing all Americans into the information age will require a momentous effort on the scale of the federal project that brought electricity to darkened regions of the country during the New Deal. However, in the absence of such an initiative, we must continue to move forward with local and state initiatives and as social workers engage in policy practice that reaches vulnerable groups in the digital divide including low-income communities, people of color, older, and rural populations. Using a slightly modified version of Bliss's (2015) model of advocacy, we propose a six-step model for social workers to utilize in digital inclusion activism, recognizing that state and local contexts will shape the specifics of strategic decisions that are made at each point along the way. However, drawing upon existing digital activism efforts and the best policy and program practices that have emerged in states with extant broadband access initiatives, we suggest a number of goals that might be useful for newly forming coalitions to consider.
In a review of the literature on the advocacy process, Bliss (2015) identifies five components of a framework for thinking about engaging in policy advocacy which we might use to reduce the digital divide. These include (1) identifying the cause and beneficiary of the advocacy campaign, (2) specifying an intended outcome, (3) identifying target audiences, (4) specifying strategies and tactics, and (5) constructing a plan for evaluating advocacy processes and outcomes. We have added a component that we believe should occur at the beginning of Bliss's model: developing an appropriate structure for coordinating advocacy efforts. We will consider each stage in turn.

\section{Forming an Advocacy Structure}

First, social workers will need to determine the most fitting structure for an advocacy campaign focused on digital inclusion. A variety of possibilities exist and are dependent on the impetus for the campaign, state and local agencies and organizations that may have an interest, and the level of change that the advocates are attempting to leverage. For example, social workers might launch such a campaign under the structure of an NASW State Chapter policy committee, as part of a multiagency campaign to increase client access to tele-health services or as part of a local chapter of a national digital inclusion organization. Because digital inclusion requires a fairly expansive involvement by either local or state government, a coalition model seems appropriate for marshalling the influence that multiple stakeholders could exert upon elected officials who might move model legislation forward. With the social distancing needs of those providing social services, health care, and mental health services to low income and rural populations during the era of Covid-19, it might be an opportune time for state actors to create coalitions of digital access activists among the providers accepting Medicaid and/or working with state contracted services. The National Digital Inclusion Alliance might be a useful organization with whom social workers might form coalitions, as they currently work with 44 state organizations that include libraries, universities, school districts, and others with a vested interest in seeing an expansion of digital access (National Digital Inclusion Alliance 2020).

\section{Clarifying Cause and Beneficiaries}

Second, Bliss states that social workers should clarify the nature of their cause and the intended beneficiaries of their advocacy. In this case, the cause is clear-to increase access to and adoption of affordable, high-speed broadband at the state or local level. However, the exact nature of the 
beneficiaries will vary somewhat based upon state contextin general though, as we have shown in our earlier literature review, the populations dealing with lower levels of Internet access and adoption include rural populations, residents of tribal reservations, the elderly, people of color, and lowincome citizens.

\section{Articulating a Desired Outcome}

Third, what is the intended outcome? Bliss notes that advocacy efforts are intended to bring about some change in the status of the beneficiary. Again, the exact nature of policy change that can occur in the area of reducing the digital divide will depend upon the political context of the state or locality in question. Generally speaking, one would posit that more liberal states (e.g., California) are more likely to have more expansive digital inclusion policies and are more likely to use government sponsored Internet providers rather than rely solely upon private, for-profit providers for access. However, this is not always the case, as we see in the Chattanooga model, where local government provides a public option for Internet services.

Fortunately, social workers do not have to develop possible outcomes of interest on their own. A variety of models of public policy and governmental action for digital inclusion, as we have seen, currently exist. A recent study by the Pew Charitable Trusts (2020) examined state broadband programs nationwide. Findings reveal a variety of state initiatives reflecting diverse state political and economic contexts. After conversations with 300 broadband stakeholders including Internet service providers (ISPs), representatives of state broadband programs, local governments, and broadband coalitions, the study highlights five practices that a number of states have taken that are proving effective. Practices reflect activities that stakeholders identified as central to the progress they have made. These promising practices are mutually reinforcing, frequently done simultaneously, and include (a) a clear plan for stakeholder outreach and engagement; (b) a policy framework with well-defined goals including the creation of tasking agencies or establishing separate offices to lead statewide broadband programs, plans for identifying barriers in unserved and underserved areas, and initiatives that connect broadband to other policy priorities such as economic development, transportation, education, and health care to build partnerships and leverage more funding; (c) planning and capacity building goals that help educate community members, identify needs and goals, and start conversations with ISPs, evaluate options, and move toward implementing infrastructure projects; (d) funding and operations that provide support for broadband deployment in unserved and underserved areas through grant programs and which include accountability measures to ensure that grantees demonstrate they are providing the service they were funded to deliver; and (e) program evaluations which effectively explore the performance of their efforts and update goals and activities as their programs mature.

When engaging in efforts to increase Internet connectivity, advocates have focused on three key aspects: universality, affordability, and reliability. Regardless of neighborhood location, economic level, legal status, or racial/ethnic identity every resident should be able to connect. Pricing must be affordable and include discounted and free accounts to low-income community members. Finally, Internet speed must be consistent and fast. These should be central goals for any advocacy effort in the area of digital inclusion.

It is also vital that the outcome of digital inclusion efforts does not end with connectivity. Strategies for affordable hardware, technical literacy training, and technical support should also be part of the plan for digital inclusion. Hardware devices are constantly being improved, and as noted earlier, some populations disproportionately rely solely on smartphones. Initiatives are needed to make sure that appropriate hardware for each broadband system is affordable and accessible. Examples include creating affordable computer purchasing plans through local governments or local non-profits, developing partnerships to distribute free and donated hardware to underserved community members, soliciting corporate donations, and including access to hardware with assistive technologies to ensure access by differently abled users.

Affordable and culturally appropriate digital literacy programs are also necessary to guarantee community members know how to access and effectively use the Internet. Examples of best practices to include as outcomes within state agency efforts include collaborating with the local school system to stay current with curricula, including content on digital privacy and security in trainings to reduce predatory outcomes including identity fraud, making a list of resources and a map of training and support programs in local communities, and identifying and making available clear pathways to access online information in many languages spoken in diverse communities.

\section{Identifying a Target Audience}

Fourth, Bliss notes that social workers must be clear about the target audience for their advocacy messaging. Advocacy efforts are directed toward specific parties who are considered as capable of bringing about changes and outcomes. In this case, candidates and elected officials in the state legislatures or in statewide offices such as governors, lieutenant governors, and state treasurers are likely to have influence in the creation and implementation of digital access programs. Appointed officials directing state agencies are also going 
to be key constituencies for the successful development and implementation of digital inclusion policies. The Pew Foundation has noted the importance of strong leadership from governors, legislators, and agency heads in successful development of digital inclusivity initiatives. If a governor's office lacks focus on broadband as a priority, other state agencies will lack energy around broadband goals, so advocacy efforts should be targeted to them early on. Similarly, successful broadband programs establish strong relationships with multiple stakeholder groups. In order to play a central role in facilitating coordination and advancing broadband projects, community stakeholders must be viewed as trusted partners, and they should be brought on board early in the advocacy process.

\section{Selecting Strategies and Tactics}

Fifth, Bliss suggests that advocates must identify strategies and tactics that will be used to influence the target audience and generate the desired outcomes. Media Alliance is a California-based media change and resource organization founded in 1976 that engages in activism including digital inclusion. They offer ideas for engaging with policymakers and the public. Examples include attending public meetings, testifying at public hearings and distributing your comments to the press, inviting your elected officials to visit and witness successful digital inclusion projects in your community, organizing local coalition members to apply for larger city or regional task force seats, and organizing town hall meetings with local organizations and testimonials from people impacted by digital exclusion.

People living in digital deserts are unlikely to obtain announcements for local events related to digital equity issues. Thus, it is important to consider distributing copies of digital inclusion meetings and initiatives through local social service agencies and other community meetings. Media Alliance provides a toolkit of resources designed to help those who want to advance digital inclusion. There are several key aspects to reducing the digital divide and all can be entry points for social workers to help advance this cause. Among them are Internet connectivity, affordable and accessible hardware, and training and technical support (i.e., digital literacy) (For a full discussion of toolkit ideas and strategies see: https://media-alliance.org/wp-content/uploads/ 2016/05/Media-Alliance-Digital-Inclusion-AdvocacyToolkit.pdf).

\section{Advocacy Process and Outcome Evaluation}

Finally, Bliss argues that advocates must identify how they will evaluate advocacy processes and actions. Without an evaluation component, the advocating entity will lack formative and summative feedback to assess their advocacy efforts and share with others. Thus, process goals must be developed and outcomes specified so that social work advocates can document their successes and failures throughout the process and at the outcome level so that the evidence base in macro social work practice can be built and best practices can be disseminated to other state advocates working on digital inclusivity policies. Advocates might consider consulting with or collaborating on evaluation with local universities. For example, the University of Kansas' Center for Community Health and Development offers useful advice and a toolbox for community practitioners who wish to develop evaluations for their initiatives (University of Kansas 2020).

\section{Conclusion}

Social work has a long and strong history of engaging in advocacy efforts alongside marginalized segments of society. Digital inclusion is a human right largely overlooked in macro social work practice and policy advocacy. Tackling the digital divide will require an approach that not only expands access but also provides digital skills and encourages people to use the Internet in ways that positively contribute to their social, economic, and political lives. In the simplest sense, social work tasks involve working collaboratively to advance people's access to resources. In the digital age, access, adoption, and digital literacy are imperative resources. This calls upon social workers to help identify and advocate for communities who continue to experience the digital divide.

\section{References}

Allen, K.D., Wallace, D.P., Renes, D., Bowen, S.L., \& Burke, R.V. (2010). Use of video modeling to teach vocational skills to adolescents and young adults with autism spectrum disorders. Education \& Treatment of Children, 33(3), 339-349. https://doi. org/10.1177/2F001440291308000103

Arizona State University (2019). ASU study: much of Indian Country lacks access to Internet, but $5 G$ expansion could be a chance to catch up. Retrieved from https://alumni.asu.edu/20191018-solutions-asu-studynative-americans-lack-internet-access-5g-opportunity-catch-up

Belluomini, E (2017). Technology in private practice, In S, Walfish, J. Zimmerman, \& J. Barnett (Eds.). Handbook of private practice: Keys to success for mental health practitioners. London, England: Oxford University Press.

Bentley, K. (2020). 9 million students lack home Internet for remote learning. Government Technology, June 11, 2020. Retrieved from https://www.govtech.com/network/9-Million-Students-LackHome-Internet-for-Remote-Learning.html

Bliss, D.L. (2015). Using the social work advocacy practice model to find our voices in service advocacy. Human Service Organizations: Management, Leadership \& Governance, 39(1), 57-68. https://doi.org/10.1080/23303131.2014.978060 
Burchardt, T., Le Grand, J., \& Piachaud, D. (1999). Social exclusion in Britain 1991-1995. Social Policy \& Administration, 33, 227-244. https://doi.org/10.1111/1467-9515.00148

California Assembly Bill No 1665 (2017). Retrieved from https:// leginfo.legislature.ca.gov/faces/billTextClient.xhtml?bill_id= 201720180AB1665

Campos-Castillo, C. (2015). Revisiting the first-level digital divide in the United States: gender and race/ethnicity patterns, 20072012. Social Science Computer Review, 33(4), 423-439. https:// doi.org/10.1177/2F0894439314547617

Carlson, E. \& Goss, J. (2016). The state of the urban/rural digital divide. National Telecommunications and Information Administration, August 10, 2016. https://www.ntia.doc.gov/blog/2016/ state-urbanrural-digital-divide

Castro, A. (2020, August 6). Feds move to block California's net neutrality law. The Verge. Retrieved from https://www.theverge. com/2020/8/6/21357013/justice-department-net-neutrality-fcclaw-throttling-isps

Close the divide (2020) https://www.idahobe.org/close

Cosner Berzin, S., Singer, J., \& Chan, C. (2015). Practice innovation through technology in the digital age: a grand challenge for social work. Grand Challenges for Social Work Initiative, working paper No. 12. American Academy of Social Work and Social Welfare.

Council on Social Work Education (2015). Educational policy and accreditation standards. Retrieved from https://www.cswe. org/getattachment/Accreditation/Accreditation-Process/2015EPAS/2015EPAS_Web_FINAL.pdf.aspx

Duggan, M., \& Smith, A. (2013, September 16). Cell Internet use 2013. Pew Research Center. Retrieved from https://www. pewinternet.org/2013/09/16/cell-internet-use-2013/

Fairlie, R. (2005). The effects of home computers on school enrollment. Economics and Education Review, 24(5), 533-547.

Federal Communications Commission (2020). In the matter of extending wireless telecommunications services to tribal lands. Report and Order and Further Notice of Proposed Rulemaking, WT Docket No. 99-266, FCC 00-209, Adopted June 8, 2000. Retrieved from https://wireless.fcc.gov/auctions/general/ releases/fc000209.pdf

Federal Communications Commission (2019). 2019 Broadband deployment report. Retrieved from https://docs.fcc.gov/public/ attachments/FCC-19-44A1.pdf

Federal Communications Commission (2018). 2018 Broadband deployment report. Retrieved from https://www.fcc.gov/reportsresearch/reports/broadband-progress-reports/2018-broadbanddeployment-report

Fox, S. (2011). Americans living with disabilities and their technology profile. Pew Internet and American Life Project. Retrieved from https://pewinternet.org/Reports/2011/Disability.aspx

Gilliard, C. (2016). Digital redlining, access, and privacy. Common Sense Education. Retrieved from https://www.commonsense. org/education/articles/digital-redlining-access-and-privacy

Government Accountability Office (GAO) (2018). FCC's data overstate access on tribal lands. Retrieved from https://www.gao. gov/products/GAO-18-630

Government Accountability Office (GAO) (2017). U.S. Postal Service: Key considerations for restoring fiscal sustainability. Retrieved from https://www.gao.gov/assets/690/682534.pdf

Government Accountability Office. (2006). Telecommunications: broadband deployment is extensive throughout the United States, but it is difficult to assess the extent of deployment gaps in rural areas (GAO Publication No GAO-06-426) Washington DC: U.S. Government Printing Office.

Horrigan, J. B. (2016). Lifelong learning and technology. Pew Research Center. Retrieved from https://www.pewresearch.org/internet/
wp-content/uploads/sites/9/2016/03/PI_2016.03.22_EducationalEcosystems_FINAL.pdf

Human Rights Watch (2019). World report 2019: Events of 2018. Retrieved from https://www.hrw.org/sites/default/files/world_ report_download/hrw_world_report_2019.pdf

International Federation of Social Workers (2012). Human rights policy. Retrieved from https://www.ifsw.org/human-rights-policy/

International Telecommunication Union (2016). ICT facts and figures 2016. Retrieved from https://www.itu.int/en/ITUD/ Statistics/Documents/facts/ICTFactsFigures2016.pdf

Jaeger, P. T., Bertot, J. C., Thompson, K. M., Katz, S. M., \& DeCoster, E. J. (2012). The intersection of public policy and public access: digital divides, digital literacy, digital inclusion, and public libraries. Public Library Quarterly, 31(1), 1-20. https://doi. org/10.1080/01616846.2012.654728

Jayakar, K., Maitland, C., Peha, J., Strover, S., Bauer, J. 2016 Broadband 202: report of the interdisciplinary workshop on the development of a national broadband research agenda Penn State University, State College, PA Institute for Information Policy.

Jorgensen, M., Morris, T., \& Feller, S. (2014). Digital inclusion in native communities: the role of tribal libraries. Oklahoma City, OK: Association of Tribal Archives, Libraries, and Museums. Retrieved from https://www.atalm.org/?q=node/312

Kang, C. (2019, February 1). Net neutrality repeal at stake as key court case starts. New York Times. Retrieved from https:// www.nytimes.com/2019/02/01/technology/net-neutralityrepeal-case.html

Kang, C. (2016, June 4). Court backs rules treating Internet as utility, not luxury. New York Times. Retrieved from https://www. nytimes.com/2016/06/15/technology/net-neutrality-fcc-appealscourt-ruling.html

Klein, E. (2014, April 6). Why the government should provide Internet access. Vox. Retrieved from https://www.vox.com/2014/4/6/ 5587138/susan-crawford-internet-public-option

Kruger \& Gilroy (2019). Broadband Internet access and the digital divide: federal assistance programs. Congressional Research Service. Retrieved from https://crsreports.congress.gov/product/ details?prodcode $=$ RL30719

Kuilema, J. (2012). Social workers and broadband advocacy: social justice and information communication technologies. Social Science Computer Review. https://doi.org/10.1177/0894439312454266

Lecher, C. (2019, May 30). Experts are furious over the FCC's rosy picture of broadband access: the data the agency uses has been criticized as flawed. The Verge. Retrieved from https://www.theverge. com/2019/5/30/18644726/fcc-broadband-report-high-speed-ruralstatistics-reactions

McGill, M.H. (2018, February 7). The least connected people in America. Politico. Retrieved from https://www.politico. com/agenda/story/2018/02/07/rural-indian-reservationsbroadband-access-000628

Macartney, S., Bishaw, A., \& Fontenot (2013). Poverty rates for selected detailed race and Hispanic groups by state and place: 2007-2011. American Community Survey Briefs. Retrieved from https:// www2.census.gov/library/publications/2013/acs/acsbr11-17.pdf

McCabe, D. (2019, October 1). Court upholds net neutrality repeal with some caveats. New York Times. Retrieved from https:// www.nytimes.com/2019/10/01/technology/net-neutrality-repealbroadband.html

Makinen, M. (2006). Digital empowerment as a process for enhancing citizens' participation. E-learning and Digital Media, 3(3), 381-395. https://doi.org/10.2304/2Felea.2006.3.3.381

Media Alliance (n.d.). About Us. Retrieved from https://mediaalliance. org/about-us/

Microsoft (2019). Nextlink Internet and Microsoft closing broadband gap in central US. Microsoft News Center. Retrieved from https:// 
news.microsoft.com/2019/09/18/nextlink-internet-and-microsoftclosing-broadband-gap-in-central-us/

Morton, H. (2019, December 21). Net neutrality 2019 legislation. National Conference of State Legislatures. Retrieved from https://www.ncsl.org/research/telecommunications-andinformation-technology/net-neutrality-2019-legislation.aspx

Mossberger, K., Tolbert, C. J., \& Stansbury, M. (2003). Virtual inequality: beyond the digital divide. Washington DC: Georgetown University Press.

Murdach, A. D. (2011). Is social work a human rights profession? (Commentary). Social Work, 56(3), 281-283.

National Association of Social Workers (2017). NASW, ASWB, CSWE, \& CSWA standards for technology in social work practice. Washington DC. Retrieved from https://www.socialworkers. org/Practice/Clinical-Social-Work/Technology

National Council of Teachers of Mathematics (2015). Strategic use of technology in teaching and learning mathematics. Retrieved from https://www.nctm.org/Standards-and-Positions/PositionStatements/Strategic-Use-of-Technology-in-Teaching-andLearning-Mathematics/

National Digital Inclusion Alliance (2020). A unified voice for digital inclusion policies and programs. Retrieved from https:// www.digitalinclusion.org/

Neidig, H. (2017). Civil rights lawyer accuses AT\&T of discriminating against low-income communities. The Hill. Retrieved from https://thehill.com/policy/technology/347818-civil-rights-lawyer-accuses-att-of-discriminating-against-low-income

New York Times Editorial Board (2020). Locked out of the virtual classroom. Retrieved from https://www.nytimes.com/2020/03/ 27/opinion/coronavirus-internet-schools-learning.html

Nyc.gov (2015). One New York: the plan for a strong and just city. Retrieved from https://onenyc.cityofnewyork.us/reports-resources/

O'Toole, J. (2014, May 20). Chattanooga's super-fast publically owned Internet. CNNMoney. Retrieved from https://money.cnn. com/2014/05/20/technology/innovation/chattanooga-internet/

Pace, P. (2010, October). Broadband access prioritized: many people are not able to afford the cost. NASW News, 55, 6 .

Perron, B., Taylor, H., Glass, J., \& Margerum-Leys, J. (2010). Information and communication technologies in social work. Advances in Social Work, 11(1), 67-81. https://doi.org/10.18060/241

Pew Charitable Trusts (2020). How states are expanding broadband access: new research identifies tactics for connecting unserved communities. Retrieved from https://www.pewtrusts.org/en/researchand-analysis/reports/2020/02/how-states-are-expandingbroadband-access

Pew Research Center (2019). Mobile fact sheet. Retrieved from https://www.pewresearch.org/internet/fact-sheet/mobile/

Queiro-Tajalli, I., Campbell, C., \& McNutt, J. (2003). International social and economic justice and on-line advocacy. International Social Work, 46, 149-161. https://doi.org/10.1177/2F0020872803046002002

Real, B., Bertot, C., \& Jaeger, P. T. (2014). Rural public libraries and digital inclusion: issues and challenges. Information Technology \& Libraries, 33(1), 6-24. https://doi.org/10.6017/ital.v33i1.5141

Rienhart, J. M., Thomas, E., \& Toriskie, J. M. (2011). K-12 Teachers: technology use and the second level digital divide. Journal of Instructional Psychology, 38(3), 181-193.

Rideout, V. \& Katz, V.S. (2016) Opportunity for all? Technology and learning in lower-income families. A report of the Families and Media Project. New York: The Joan Ganz Cooney Center at Sesame Workshop. Retrieved from https://joanganzcooneycenter. org/publication/opportunity-for-all-technology-and-learning-inlower-income-families/

Ritzhaupt, A. D., Liu, F., Dawson, K., \& Barron, A. E. (2013). Differences in student information and communication technology literacy based on socioeconomic status, ethnicity, and gender. Evidence of a digital divide in Florida schools. Journal of Research on Technology in Education, 45(4), 291-307.

Ruiz, R.R. (2015, March 12). F.C.C. sets net neutrality rules. The New York Times. Retrieved from https://www.nytimes.com/2015/03/ 13/technology/fcc-releases-net-neutrality-rules.html

Ryan, C. (2018). Computer and Internet use in the United States: 2016 American Community Survey Reports, ACS-39, U.S. Census Bureau, Washington DC, 2017. Retrieved from https://www. census.gov/content/dam/Census/library/publications/2018/acs/ ACS-39.pdf

Stuhlmiller, C., \& Tolchard, B. (2009). Computer-assisted CBT for depression and anxiety: increasing accessibility to evidence-based mental health treatment. Journal of Psychosocial Nursing And Mental Health Services, 47(7), 32-39. https://doi.org/10.3928/ 02793695-20090527-01

Tarnoff, B. (2016, August 3). The Internet should be a public good. Jacobin. Retrieved from https://www.jacobinmag.com/2016/08/ internet-public-dns-privatization-icann-netflix/

Tomer, A., Kneebone, E. \& Shivaram, R. (2017). Signs of digital distress: mapping broadband availability and subscription in American neighborhoods. The Brookings Institution, Metropolitan Policy Program. Retrieved from https://www.brookings.edu/wpcontent/uploads/2017/09/broadbandreport_september2017.pdf

United Nations General Assembly (2016). Human Rights Council thirty-second session, agenda item 3: promotion and protection of all human rights, civil, political, economic, social and cultural rights, including the right to development. Retrieved from https:// www.article19.org/data/files/Internet_Statement_Adopted.pdf

United States Census Bureau (2017). The digital divide: percentage of households by broadband Internet subscription, computer type, race and Hispanic origin. September 11, 2017. Retrieved from https:// www.census.gov/library/visualizations/2017/comm/internet.html

United States Postal Service (2011). 2010 Comprehensive Statement on Postal Operations, 2010 Performance Report and 2011 Performance Plan. Chapter 1: our mission. Retrieved from https://about. usps.com/strategic-planning/cs09/CSPO_09_002.htm

United States Senate Bill 652 (1996). Telecommunications Act of 1996. Retrieved from https://www.congress.gov/bill/104th-congress/ senate-bill/652

University of Kansas Center on Community Health and Development. (2020). Evaluating the initiative (Community Tool Box). Retrieved from https://ctb.ku.edu/en/evaluating-initiative

VanDeMark, N., Burrell, N., Lamendola, W., Hoich, C., Berg, N., \& Medina, E. (2010). An exploratory study of engagement in a technology-supported substance abuse intervention. Substance Abuse Treatment, Prevention, and Policy, 5(10), https://doi.org/ 10.1186/1747-597X-5-10

Vick, K. (2017, March 30). The digital divide: a quarter of the nation is without broadband. Time. Retrieved from https://time.com/ 4718032/the-digital-divide/

Waldman, P. (2020, August 13). Trump's attack on the postal service is now a national emergency. Washington Post. Retrieved from https://www.washingtonpost.com/opinions/2020/08/13/trumpsattack-postal-service-is-now-national-emergency/

Walravens, S. (2020, June 8). Why online learning is failing our nation's most vulnerable students. Forbes. Retrieved from https://www.forbes.com/sites/geekgirlrising/2020/06/08/newreport-shows-impact-of-digital-divide-on-low-income-students/\# 7 afe 48811701

Wang, H.L. (2018, December 6). Native Americans on tribal land are the least connected to high-speed Internet. NPR National. Retrieved from https://www.npr.org/2018/12/06/673364305/ native-americans-on-tribal-land-are-the-least-connected-to-highspeed-internet 
Warf, B. (2012). Contemporary digital divides in the United States. Journal of Economic and Social Geography, 104(1), 1-17. https:// doi.org/10.1111/j.1467-9663.2012.00720.x

West, D.M., \& Karsten, J. (2016). Rural and urban America divided by broadband access. Brookings Institute, July 16, 2016. Retrieved from https://www.brookings.edu/blog/techtank/2016/07/18/ruraland-urban-america-divided-by-broadband-access/

West, J. C. (2011). Without a net: librarians bridging the digital divide. Santa Barbara, CA: Libraries Unlimited.

Wood, C. (2017, October 27). To close the digital divide, California approves $\$ 330$ million broadband infrastructure fund. Statescoop. Retrieved from https://statescoop.com/to-close-the-digital-dividecalifornia-approves-330-million-broadband-infrastructure-fund/
Wronka, J. (2016). Human rights and social justice: social action and service for the health and helping professions. Thousand Oaks, CA: Sage.

Youn, E. (2007). The relationship between technology content in a masters of social work curriculum and technology use in social work practice: a qualitative research study. Journal of Technology in Human Services, 25(1-2), 45-58. https://doi.org/10.1300/ J017v25n01_03.

Zeke (2014, November 10). Obama bucks FCC in calling for broadband reclassification. TIME. Retrieved from https://time.com/ 3575842/obama-broadband-internet/ 